\title{
Synthesis, Characterization and Antibacterial Application of ZnO Thin films
}

\author{
A M Wagh ${ }^{1}$ | N U Patil ${ }^{1}$
}

${ }^{1}$ Department of Physics, MVP Samaj's , K. K. Wagh Arts, Science and Commerce College, Pimpalgaon (B.) Tal- Niphad, Dist- Nashik

To Cite this Article

A M Wagh and N U Patil, "Synthesis, Characterization and Antibacterial Application of ZnO Thin films", International Journal for Modern Trends in Science and Technology, Vol. 07, Issue 02, February 2021, pp.-13-16.

\section{Article Info}

Received on 12-January-2021, Revised on 26-January-2021, Accepted on 29-January-2021, Published on 01-February-2021.

\section{ABSTRACT}

The objective of this study is to synthesize $\mathrm{ZnO}$ nano particles in form thin film on glass substrate and study antibacterial active of such films. ZnO thin films were prepared by spray pyrolysis technique using zinc acetate and isopropyl alcohol as precursor in the temperature range $375^{\circ} \mathrm{C}$ to $425^{\circ} \mathrm{C}$. The optical properties of the film were studied on UV/VIS/NIR spectrophotometer. The energy gap of the film is evaluated and it is found to be $3.31 \mathrm{eV}$. The polycrystalline nature of the $\mathrm{ZnO}$ film was confirmed by structural analysis by Xray diffraction method and the grain size is determined. It is found to be 50nm. The electrical resistivity of the film was measured by four probe method at different temperatures and it is found that electrical resistivity varying in the range $10^{3}$ to $10^{4} \Omega-\mathrm{cm}$. we studied the antibacterial activity of ZnO thin film against gram-negative bacteria. Escherichia coli ( $E$-coli) were used as test micro organisms. It is found that $Z n O$ film enhanced the significant antibacterial activity.

Keywords: ZnO, Optical properties, Structural properties, Electrical properties, Antibacterial activity

\section{INTRODUCTION}

Zinc Oxide $(\mathrm{ZnO})$ is one of the most promising transparent conducting oxides (TCO) [1]. $\mathrm{ZnO}$ is an $\mathrm{n}$ - type semiconductor having wurtzite structure. It has unique and interesting properties such as wide band gap $(3.37 \mathrm{eV})$ at room temperature [2], large excitation binding energy $(60 \mathrm{MeV})$ at room temperature [2], high thermal and chemical stability [3], non toxicity [4], good electrical and optical behavior [5], photo catalytic activity and antibacterial activity $[6,7,8]$.

Several researchers has already done more work on zinc oxide in the last few decades, but still it is one of the favorite conducting oxide for the variety of applications such as optoelectronics, gas sensors, light emitting diodes, photo detectors, liquid crystal displays, solar cells $[9,10,11]$.
To improve $\mathrm{ZnO}$ properties many growth techniques are used such as chemical bath deposition [5], hydrothermal [9], spin coating [10], screen printing [11], chemical refluxing [12], electro deposition [15]. In this paper undoped $\mathrm{ZnO}$ thin films were prepared by spray pyrolysis technique. Spray pyrolysis is one of the traditional methods to deposit thin films. It has low cost and simple mechanism over all other techniques $[1,2,3$, 4 , and 13].

\section{EXPERIMENTAL DETAILS}

ZnO films are prepared on glass substrate by spray pyrolysis technique. The spray solution is zinc acetate, isopropyl alcohol and distilled water. In order to get $0.1 \mathrm{M}$ homogeneous transparent solution of zinc acetate, $2.195 \mathrm{gm}$ of zinc acetate is 
dissolved in $20 \mathrm{ml}$ isopropyl alcohol and stirred at room temperature.

The substrate temperature and molar concentration of precursor solution is varied by keeping other process parameter constant.

Temperature of the substrate is varied from $375^{\circ} \mathrm{C}$ to $425^{\circ} \mathrm{C}$. The spray gun used to spray the solution has diameter $0.3 \mathrm{~mm}$. Volume of solution sprayed is about $90 \mathrm{ml}$ to $100 \mathrm{ml}$. Air flow rate is maintained at $18 \mathrm{Lpm}$.

\section{Chemical reaction}

$\mathrm{Zn}\left(\mathrm{CH}_{3} \mathrm{COO}\right)_{2} \cdot 2 \mathrm{H}_{2} \mathrm{O}+\mathrm{CH}_{3} \mathrm{CHOHCH}_{3} \rightarrow \mathrm{ZnO}+$ $2 \mathrm{CH}_{3} \mathrm{COOH}(\uparrow)+\mathrm{CH}_{3} \mathrm{CH}_{2} \mathrm{CH}_{3}(\uparrow)+\mathrm{H}_{2} \mathrm{O}(\uparrow)$

\section{STRUCTURAL PROPERTIES}

In order to understand the structural properties of $\mathrm{ZnO}$ thin films, $\mathrm{x}$-ray diffraction technique is carried out in the range $20^{\circ} \mathrm{C}$ to $80{ }^{\circ} \mathrm{C}$ using $\mathrm{CuK}_{\mathrm{a}}$ radiation.

Fig. 1 shows XRD pattern of $\mathrm{ZnO}$ thin film at temperature $400{ }^{\circ} \mathrm{C}$. From the graph we can see that one sharp and five small peaks are present. It can be seen that the prepared $\mathrm{ZnO}$ material is polycrystalline in nature. The highest peak (002) intensity for $\mathrm{ZnO}$ is located at angle $34.4^{\circ}$.

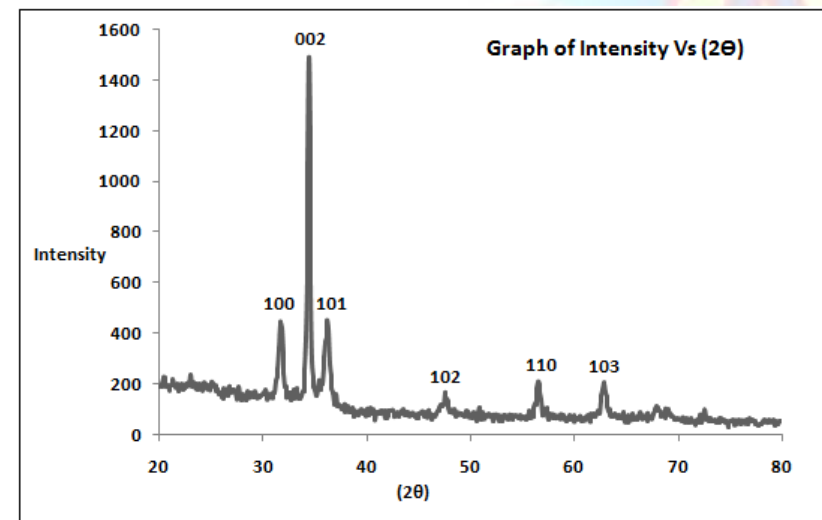

Fig. $1 X$ - ray diffraction pattern

The average grain size are calculated from XRD data and using Debye scherer's formula [9],

$$
\mathrm{D}=0.94 \lambda / \beta \cos \theta_{\mathrm{B}}
$$

Where, $\quad \lambda=$ wavelength of $\mathrm{x}$-ray $(1.542 \mathrm{~A})$

$B=$ full width at half maximum of the diffraction peaks in radians $(0.3)$

$\theta_{\mathrm{B}}=$ Bragg's angle in degrees (17.2)

For calculating grain size, FWHM of only highest intensity reflection was considered.

\section{OPTICAL PROPERTIES UV Spectroscopy-}

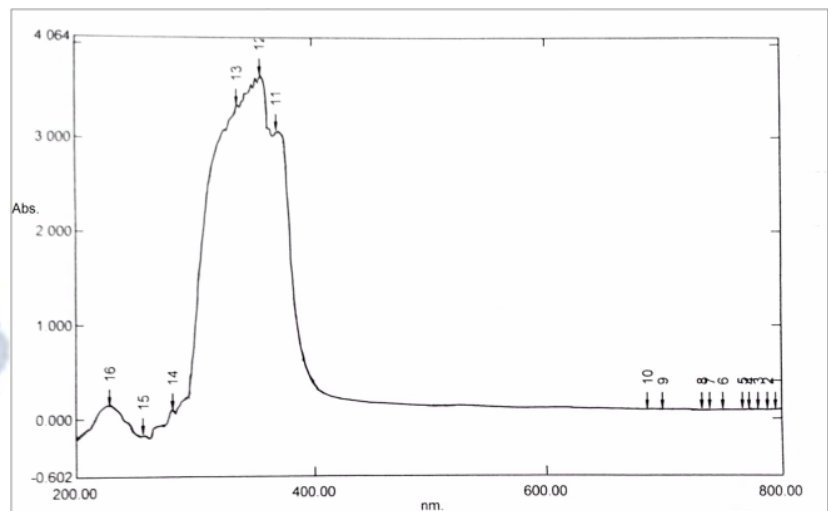

Fig. 2 UV/VIS absorption curve

Fig. 2 shows the variation of absorbance (at) of $\mathrm{ZnO}$ thin film. Fig. 2 indicates that the prepared $\mathrm{ZnO}$ film has low absorbance in the visible region, which is one of the characteristics of $\mathrm{ZnO}$.

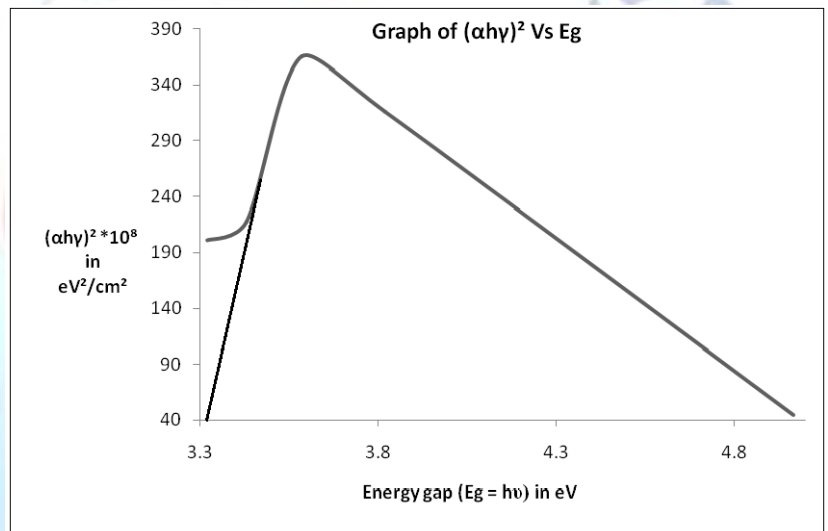

Fig. 3 graph of $(a h v)^{2}$ Vs (hv)

The band gap of the film is calculated by using the equation,

$\mathrm{a}=\left(\mathrm{hu}-\mathrm{E}_{\mathrm{g}}\right)^{1 / 2} / \mathrm{hu}$

From this equation we can plot a graph of $(\mathrm{ahu})^{2} \mathrm{Vs}$ (hu) for $\mathrm{ZnO}$ film. From fig. 3 the direct band gap energy is found to be $3.31 \mathrm{eV}$ for the prepared $\mathrm{ZnO}$ film.

\section{IR Spectroscopy}

Infrared spectroscopy is carried out to understand the molecular structure, chemical bonding and the functional groups. Fig. 4 shows IR spectrum of the $\mathrm{ZnO}$ thin film. Frequency band of the spectrum located at $557.43 \mathrm{~cm}^{-1}$ could be assigned for bending and stretching vibrations of $\mathrm{Zn}-\mathrm{O}$ bonds. 


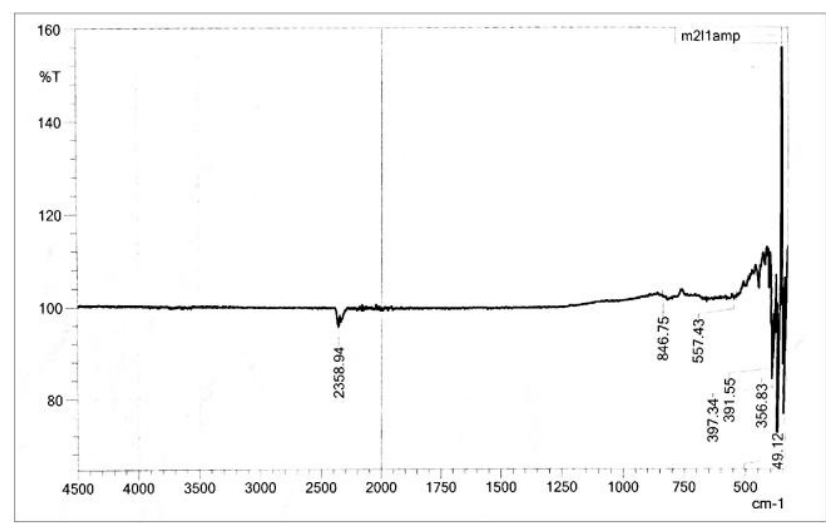

Fig. 4 IR transmission curve

\section{ELECTRICAL PROPERTIES}

The electrical resistivity of $\mathrm{ZnO}$ films is measured by four probe method at different temperatures $(25$ ${ }^{\circ} \mathrm{C}$ to $100^{\circ} \mathrm{C}$ )

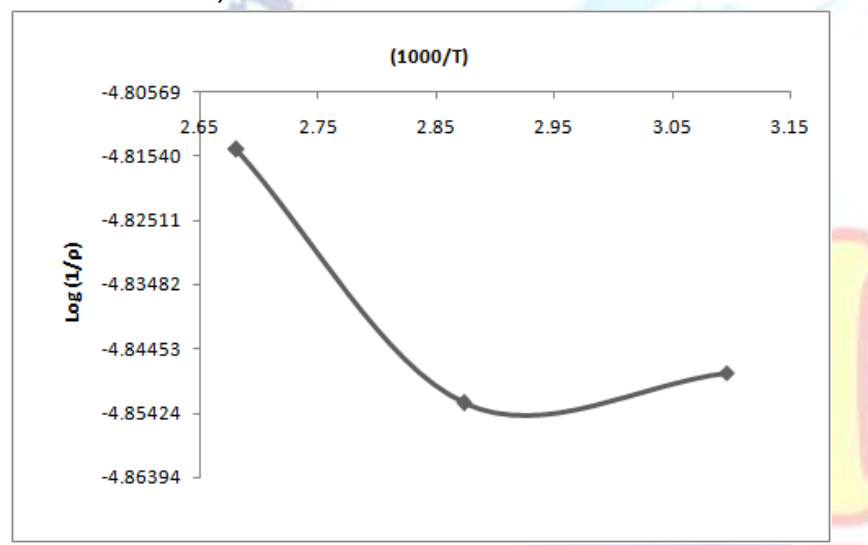

Fig. 5 Variation of electrical resistivity

(1000/ T) Vs Log $(1 / \rho)$

Fig. 5 shows the variation of electrical resistivity $(\log 1 / \rho)$ with temperature $(1000 / \mathrm{T})$. It is seen that the resistivity of $\mathrm{ZnO}$ film goes on decreasing with increase in temperature. This shows that the $\mathrm{ZnO}$ film has negative temperature coefficient. This also indicates that the $\mathrm{ZnO}$ film has semiconductor nature. The electrical resistivity is of the order of $10^{3}$ to $10^{4} \Omega-\mathrm{cm}$.

\section{ANTIBACTERIAL ACTIVITY}

The antibacterial activity of the prepared $\mathrm{ZnO}$ thin films was studied against gram negative bacteria (Escherichia coli). These bacteria species are not purchased. They are collected from the patients and identified using standard biochemical tests. The nutrient agar is used as the bacterial culture medium. All the bacterial strains are grown aerobically in the nutrient agar for 24 hours at $37^{\circ} \mathrm{C}$ before using as a target organism [6, 7, and 8].

In order to examine the antibacterial activity of $\mathrm{ZnO}$ film, the prepared film are placed aseptically on the agar surface with the help of sterile forceps and then pressed slightly with the forceps to make complete contact with the surface of the medium. The plated are incubated at $37{ }^{\circ} \mathrm{C}$ and observed the inhibition after 24 hours (Fig. 6) [6, 7, and 8].

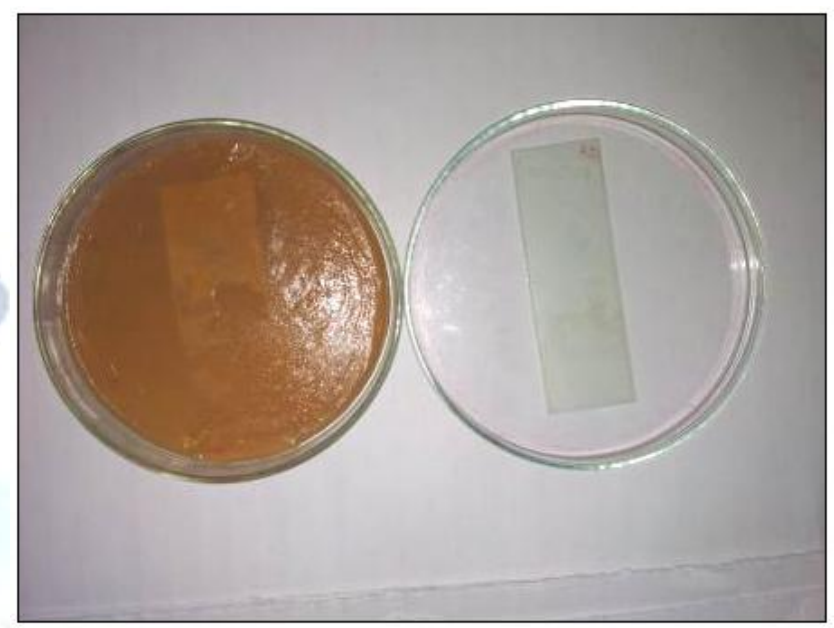

Fig. 6 Antibacterial activity of $\mathrm{ZnO}$ film against $\mathrm{E}$ coli micro organism

\section{CONCLUSIONS}

- Transparent $\mathrm{ZnO}$ thin films are successfully prepared by the spray pyrolysis technique on glass substrate at $375^{\circ} \mathrm{C}$ to $425^{\circ} \mathrm{C}$ using zinc acetate $\&$ air as a carrier gas.

- The x-ray diffraction analysis shows that the films are polycrystalline in nature. The interplaner distance is found to be $2.6048 \mathrm{~A}^{\circ}$.

- The estimated grain size is $50.53 \mathrm{~nm}$.

- Optical measurements showed that the $\mathrm{ZnO}$ film show low absorbance in the visible region. This shows that the prepared $\mathrm{ZnO}$ film possesses semiconductor nature.

- The film has the direct band gap with an optical value of $3.31 \mathrm{eV}$.

- The electrical resistivity decreases with increase in temperature. This concludes that the film has negative temperature coefficient of resistance.

- The prepared $\mathrm{ZnO}$ thin film shows significant antibacterial activity against the gram- negative bacteria E- coli.

\section{REFERENCES}

[1] C. Gumus, O. M. Ozkendir, H. Kavak, Y. Ufuktepe, Structural and optical properties of zinc oxide thin films prepared by spray pyrolysis method, Journal of optoelectronics and advanced materials, Vol. 8 (01), February-2006

[2] Abdelkader Hafdallah, Fahima Djefaflia, Narimane Saidane, Structural and optical properties of $\mathrm{ZnO}$ thin films deposited by pyrolysis spray method: Effect of substrate temperature, Optics, Vol. 7(02), September-2018 
[3] A. Tecaru, A. I. Danciu, V. Musat, E. Fortunato, E. Elangovan, Zinc oxide thin films prepared by spray pyrolysis, Journal of optoelectronics and advanced materials, Vol. 12 (09), September- 2010

[4] Fawzy A. Mahmoud, G. Kiriakidis, Nanocrystalline ZnO thin films for gas sensor application, Journal of Ovonic Research Vol. 5 (01), February- 2009

[5] C. D. Lokhande, P. M. Gondkar, Rajaram S. Mane, V. R. Shinde, Sung-Hwan Han, CBD grown $\mathrm{ZnO}$ - based gas sensors and dye- sensitized solar cells, Journal of alloys and Compounds 475 (2009)

[6] Zarrindokht Emami-Karvani and Pegah Chehrazi, Antibacterial activity of $\mathrm{ZnO}$ nanopaticle on gram- positive and gram- negative bacteria, African Journal of Microbiology Research Vol. 5(12), 18 June, 2011】

[7] G.Parthasarathy, Dr.M.Saroja, Dr.M. Venkatachalam, P. Gowthaman, Sounder. J.,Antibacterial activity of $\mathrm{ZnO}$ thin films prepared by sol-gel dip-coating method, International Journal for research in applied science and technology, Vol. 5(08), August, 2017 \

[8] Deepu Thomas, Jyothi Abraham, Sunil C. Vattappalam, Simon Augustine, Dennis Thomas T., Antibacterial activity of pure and cadmium doped $\mathrm{ZnO}$ thin film, Indo American journal of pharmaceutical research, 2014:4(03)

[9] M. K. Deore, G. H. Jain, Synthesis, characterization and gas sensing application of nano $\mathrm{ZnO}$ material, International Journal of Nanoparticles, Vol. 7(01), 2014

[10] A. P. Rambu, L. Ursu, N. Iftimie, V. Nica, M. Dobromir, F. Iacomi, Study on Ni- doped $\mathrm{ZnO}$ films as gas sensors, Applied surface science 280 (2013) 